\title{
Organizational Culture, Commitment and Job Satisfaction of Faculty in Private-Sectarian Higher Education Institutions (HEIs)
}

\author{
Maria Leodevina C. Batugal ${ }^{1, *}$ \\ ${ }^{1}$ School of Education, St. Paul University Philippines, Tuguegarao City, Philippines \\ *Correspondence: School of Education, St. Paul University Philippines, Tuguegarao City, Philippines. E-mail: \\ lbatugal@spup.edu.ph
}

Received: March 14, 2019

Accepted: April 15, 2019 Online Published: April 20, 2019

doi:10.5430/wje.v9n2p123

URL: https://doi.org/10.5430/wje.v9n2p123

\begin{abstract}
This study explored the organizational culture, organizational commitment and job satisfaction of the faculty members of the St. Paul University System (SPUS). This study employed a descriptive and correlational research design. The data gathered were analyzed and interpreted using frequency and percentage distribution to confirm statistical assumptions and to describe the participants' profile in terms of the identified variables. The weighted mean was used to interpret the responses obtained from the use of the Likert's scale. The regression analysis was used to determine the best predictors of job satisfaction and organizational commitment while Pearson and Chi-Square were used to determine the degree of relationship between the variables. The results of this study indicate that there is a significant positive relationship between job satisfaction and organizational culture. It was also found out that job satisfaction predicts organizational commitment. The results of this study will be a basis for the SPUS to strengthen the organizational commitment and explore various ways to raise the level of job satisfaction of the faculty members of the respondent-institutions.
\end{abstract}

Keywords: faculty, organizational commitment, organizational culture, job satisfaction

\section{Introduction}

Amidst an increasingly competitive environment, in any organization, the quality of human resources is a key to sustainability and productivity. Human resources are the moving force of the organization and harnessing their capabilities contribute significantly to bringing out excellence and quality. They are essential in making the organization to flourish and achieve its vision, mission, and goals. Persons are the organization's most important resource; thus it is fundamental to have a comprehensive knowledge of their "needs, values and motivations," to raise their level of commitment, satisfaction and to keep their loyalty to the organization.

What stimulates employees to stay in an organization? Are they the employees who are deeply satisfied with their job or are they the ones who work in an organization with a positive working environment? Researchers found out that employees who are satisfied with their jobs manifest loyalty to the organization (Uii, 2011; Nacpil \& Lacap, n.d). The present author believes that the employees who love their work tend to perform well. Committed employees lead to higher performance and productivity. On the contrary, dissatisfied employees with negative behavior towards their job can lead to poor service and theft.

In any organization, committed employees are necessary most likely because of the concept that loyal employees hold many implications in the organization. They can be more engaged in implementing the institution or the company's goal, plans or targets. Loyalty to the organization and the right attitude to one's job are essential values which are an integral part of an organization's culture. Organizational culture has a profound influence on individual employee precisely because it is a generally accepted set of values rather than merely thinking as an explicit, written set of values. Organizational culture is in itself organizational values passed on from one employee to employee through teachings, stories, and examples. Like the stories of George Washington, John Paul II, Theresa of Calcutta, Mahatma Gandhi, and other renowned personalities which are passed on from person to person and from year to year, so do organization's stories. They manage to convey values essential to the organization's culture.

Robert E. Quinn and Kim S. Cameroon present four types of organizational culture: Clan, Adhocracy, Market, and 
Hierarchy. They explain that the Clan-oriented culture focuses on mentoring, nurturing, and "doing things together." This culture is family-oriented. The Adhocracy-oriented culture is dynamic and entrepreneurial which focuses on risk-taking, innovation, and "doing things first." The Market-oriented culture is more of results-oriented. It focuses on competition, achievement, and "getting the job done," and finally the Hierarchy-oriented culture is structured and controlled. The latter focuses on efficiency, stability and "doing things right." Correspondingly, each organization has an organizational culture which clearly distinguishes it from other organizations. The awareness of the organization's dominant culture can facilitate each employee to adjust immediately, and it is essential for effective leadership as well. More specifically, in the academic institutions, the culture reflects the teachers' perception of the school to which they belong. This culture refers to a set of unique characteristics and features that the academic community knows about their school and which serves as a significant force in influencing their behavior.

The Paulinian education shares in the unique history and tradition of the church which is marked by "Christocentric-paschal spirituality." Its educational system is guided by the following core values; Christ-centeredness, commission, community, charism, and charity. Anastacio (2016) affirmed that as Catholic schools, Paulinian educational institutions share in the evangelizing mission of the Church which is to participate in proclaiming "the good news of salvation to all." Indeed, the Paulinian culture has a unique character which is nurtured and passed on to generations of Paulinians. The role of the Paulinian teachers, then, is crucial as they share in passing on the Paulinian culture as they carry on to their task of producing generations of Paulinians throughout the country and of the world, who give witness to the reality that: "The Paulinian is for others." It is in this light that every Paulinian school should continue its efforts in raising the level of teachers' commitment not only to their profession but to their institution as well.

In the Philippines, most of the private colleges and universities face difficulties in maintaining the commitment of teachers. Substantial evidence shows that teachers in private schools are having an exodus to the public schools. Moreover, this predicament on teachers' commitment is undoubtedly due in part to the low salary and benefits, poor working conditions, and lack of prestige of the teachers in some private colleges and universities. The resignations of tenured and qualified faculty members had caused the dearth of qualified faculty members in the said colleges and universities. The pervasiveness of this trend will have a negative impact on private schools and the St. Paul University System (SPUS) surely is not spared with such a scenario.

This condition motivated the researcher to embark on exploring the level of job satisfaction, organizational commitment and organizational culture of the faculty in the selected schools of the SPUS. The objective significance of this study, then, is clear from its potential in providing a data which will be a basis in improving the level of organizational commitment and job satisfaction of the faculty of the respondent-institutions. Moreover, the results will be a basis in formulating work-life balance programs that will benefit and cater to the needs of Paulinian educators.

\section{Literature Review}

The goal of this section is to present related studies gathered from the literature that have a relationship with the present study. Discussions of these have been important in supporting and strengthening the study in all its aspects. Various research findings in the past have shown that there is a significant relationship between job satisfaction and organizational commitment (Porter \& Mowday, 1974; William \& Anderson, 1991; Lok \& Crawford, 1999). Researches also revealed that organizational loyalty is highly related to job satisfaction. Affective organizational commitment was found to be most influential concerning levels of intrinsic and extrinsic job satisfaction (Markovits, Davis, \& Van Dick, 2007). The research which was conducted by Blance \& Menes (n.d.) found out that the employees of a retail establishment are satisfied but have a slightly high organizational commitment. Their job satisfaction is significantly related to their organizational commitment. Quiambao \& Nuqui (2017) also found in their study from among the tertiary faculty in a private institution that only educational attainment, incentives and job satisfaction significantly affect the commitment of the teachers. The present study found similarities in the previous foreign and local researches conducted. However, one component of job satisfaction (task significant) almost did not predict organizational commitment (continuance commitment). The overall result showed that job satisfaction components predict organizational commitment and conversely, the result varied from low correlation to moderate correlation.

The result of the study conducted by Sikorska (2005) showed that organizational culture, job satisfaction, and education were strong predictors of commitment. This study also found out that higher levels of organizational commitment were associated with more favorable staff perceptions of organizational culture and greater job satisfaction. The result also revealed that more educated staff members tended to report higher levels of organizational commitment. Finally, she concluded that job satisfaction and organizational culture were strong predictors of 
commitment.

Furthermore, the research conducted in Taiwan by Silverthorne (2004) revealed that an innovative culture was the next highest and a supportive culture had the highest level of employee job satisfaction and organizational commitment. The findings further indicated that organizational culture plays a vital role in the level of job satisfaction and commitment in an organization. Also, in a Korean private company, Lim (2010) found out in his research that learning organization culture is moderately and positively related to job satisfaction. He also found out that organizational commitment, except for continuance commitment, to be moderately and positively related to learning organization culture and job satisfaction. Moreover, Dadgar, Barahouei, Mohammadi, Ebrahimi, \& Ganjali (2013) conducted a study from among the health personnel of Zahedan University of Medical Sciences in Iran, and the study found that Clan culture had a positive and significant relationship while Adhocracy and Market culture type had a negative and significant relationship with the intention to stay in the organization. The study conducted by Zavyalova \& Kucherov (2010) revealed that organizations with different types of organizational culture differ in the level of job satisfaction of employees. This present study, the author found out that there is a significant positive relationship between job satisfaction and clan. This finding consistently shows that the participants in the respondent-institutions prioritize a unique need for having a clan-oriented culture. It further revealed a negative relationship between job satisfaction with the three culture profiles such as hierarchy, adhocracy, and market type of culture. The market-oriented culture did not show a significant relationship in the job satisfaction level of the participants of the respondent-institutions which find support in a study conducted by Lund (2003) that job satisfaction was positively related to clan and adhocracy cultures and negatively related to market and hierarchy cultures.

A. A. Hosseinkhanzadeh, A. Hosseinkhanzadeh, \& Yeganeh, (2013) investigated the relationship of organizational culture and job satisfaction from among middle school teachers in Tehran City in Iran. The study revealed that there was a significant relationship between organizational culture and job satisfaction. This result likewise revealed in a study conducted by Utami, Farida, Azalia, \& Lutfi (2017) from among the employees at PT Cartenz Indonesia. It revealed that organizational culture and job satisfaction significantly influence organizational commitment.

Other researches also have revealed that organizational culture correlates with a variety of individual outcomes. Studies have demonstrated that organizational culture was significantly correlated with employee attitude and behavior and was positively related with motivation, job satisfaction, teamwork, considerate leadership, quality of customer service and performance and was negatively associated with work avoidance, stress, and a supervisor's use of criticism (Cooke \& Szumal, 1993). These results found some similarities in the research conducted by Welsch \& Lavan (1981) that participative climate and teamwork are positively related to organizational commitment while role conflict and role ambiguity are disadvantageous to commitment.

The study of Noordin, Omar, Sehan, \& Idrus (2010) on organizational culture and its influence on organizational commitment indicated that in terms of the correlations between the variables, the results indicated that continuance commitment showed significant positive correlations with organizational design, teamwork, and decision-making. Overall, the findings of the study indicate that the current situation describes all the components of the organizational climate and organizational commitment.

Moreover, a survey from among American employees disclosed that more than $85 \%$ of Americans are somewhat or very satisfied with their jobs, a level that has been consistent for more than a decade. The survey also divulged that Americans have a high level of job satisfaction compared with people in most other countries. The result showed that only employees in Denmark, India, and Norway are happier at work. Interestingly, the survey showed that Asian countries were reported having lower job satisfaction (McShane \& Von Glinow, 2008). This revelation further motivated the present author to explore on the job satisfaction level of the teachers, particularly the schools of the SPUS. Likewise, she was motivated to investigate the level of organizational commitment and the dominant culture type of the respondent-institutions.

As a result of the literature review and studies, both foreign and local, this research was conceptualized and formed. The related literature and studies guided the author in building the concept that organizational culture is positively related to organizational commitment and a high level of job satisfaction is positively related to organizational commitment. The basic proposition here is that organizational commitment, job satisfaction, and organizational culture correlate with each other. 


\section{Problem Statement}

This research investigated the organizational culture, organizational commitment and job satisfaction of the tertiary faculty with full-time and permanent status in the selected schools of the SPUS in the Philippines.

Specifically, it sought to answer the following questions:

1. What is the profile of the participants in terms of:

$1.1 \mathrm{sex}$;

1.2 age;

1.3 civil status;

1.4 no. of years in present employment;

1.5 highest educational attainment;

1.6 designation; and

1.7 salary?

2. What describes the organizational culture of the faculty of SPUS?

3. What describes the organizational commitment of the faculty of SPUS?

4. What describes the job satisfaction of the faculty of SPUS?

5. Is there a significant relationship between organizational culture and job satisfaction?

6. Is there a significant relationship between job satisfaction and organizational commitment?

\section{Methodology}

\subsection{Research Design}

The primary objective of this study is to explore the commitment level, satisfaction level and the organizational culture of the tertiary faculty of the SPUS. It further investigated the relationship between organizational culture and job satisfaction; and job satisfaction and organizational commitment. In order to realize these objectives, this study employed a descriptive and correlational research design. The main concern of the research is to examine the relationship between the independent and the dependent variables.

\subsection{Sample and Sampling Procedure}

This study was conducted within the four (4) member-institutions of the SPUS which are found in Luzon, Visayas, and Mindanao. The participants are the tertiary faculty with permanent status in the said universities. In selecting the participants, the researcher made use of a stratified random sampling technique. Specific subgroups or strata were selected for the samples in the same proportion as they exist in the organization.

Table 1. Participating Institutions

\begin{tabular}{lcc}
\hline \multicolumn{1}{c}{ Participants } & Frequency (f) & Percentage (\%) \\
\hline SCHOOL A & 75 & $58.14 \%$ \\
SCHOOL B & 19 & $14.73 \%$ \\
SCHOOL C & 15 & $11.63 \%$ \\
SCHOOL D & 20 & $15.50 \%$ \\
TOTAL & 129 & $100.00 \%$ \\
\hline
\end{tabular}

The table shows the number of participants from each of the participating schools. The highest number of participants comes from School A with 75 participants or 58. 14\% followed by School D with 20 participants or $15.50 \%$, closely followed by School B with 19 participants or $14.73 \%$. The smallest population comes from School C with 15 participants or $11.63 \%$.

\subsection{Instruments and Other Sources of Data}

The following were the instruments used in gathering the data in this research:

2.3.1 Organizational Commitment Questionnaire (OCQ)

The OCQ was adapted from John Meyer and Natalie Allen. The questionnaire consists of 18 items. The Organizational Commitment scores were obtained from a 7-point Likert scale. 
Table 2. Likert-Range Conversion Table for Organizational Commitment

\begin{tabular}{ccl}
\hline Likert-Point & Range & Descriptive Interpretation \\
\hline 7 & $6.16-7.00$ & Strongly Agree (SA) \\
6 & $5.30-6.15$ & Moderately Agree (MA) \\
5 & $4.44-5.29$ & Slightly Agree (SLA) \\
4 & $3.58-4.43$ & Neither Agree nor disagree (N) \\
3 & $2.72-3.57$ & Slightly Disagree (SLD) \\
2 & $1.86-2.71$ & Moderately Disagree (MD) \\
1 & $1.00-1.85$ & Strongly Disagree (SD) \\
\hline
\end{tabular}

Table 3. Qualitative Interpretation of the Organizational Commitment Questionnaire

\begin{tabular}{cl}
\hline Range & \multicolumn{1}{c}{ Qualitative Interpretation } \\
\hline $1.00-2.50$ & Low Level of Commitment (LLC) \\
$2.51-5.50$ & Average Level of Commitment (ALC) \\
$5.51-7.00$ & High Level of Commitment (HLC) \\
\hline
\end{tabular}

2.3.2 Job Satisfaction Questionnaire (JSQ). The JSQ questionnaire consists of 65 items with thirteen (13) components.

The following are its components:

2.1 Relationship with Immediate Head

2.2 Interdepartmental Relationship

2.3 Physical Environment

2.4 Relationship with co-employees

2.5 Compensation

2.6 Job Identification

2.7 Overall attitude toward work

2.8 Clarity of Work Group

2.9 Implementations of Policies

2.10 Management

2.11 Communication

2.12 Feedbacking

2.13 Task Significant

Table 4. Qualitative Interpretation of the JSQ

\begin{tabular}{cccl}
\hline In the questionnaire & Scale & Range & Qualitative Interpretation \\
\hline A & 1 & $1.00-1.74$ & Very Dissatisfied (VD) \\
B & 2 & $1.75-2.49$ & Dissatisfied (D) \\
C & 3 & $2.50-3.24$ & Satisfied (S) \\
D & 4 & $3.25-4.00$ & Very Satisfied (VS) \\
\hline
\end{tabular}

\subsubsection{Organizational Culture Assessment Instrument (OCAI)}

The OCAI is a standardized questionnaire developed by Cameron/Quin, Diagnosing and Changing Organizational Culture (2000). It consists of 6 groups: Dominant Characteristics, Organizational Leadership, Management of Employees, Organization Glue, Strategic Emphases, and Criteria of Success. Each group has four alternatives. The first part is labeled "NOW," which refers to the culture, as it presently exists in the participants' organization. The items are repeated under a heading "PREFERRED." The answers for this part were based on how the participants would like their organization to become after five years. 
Table 5. Qualitative Interpretation of the Relationship between Organizational Culture and Job Satisfaction; and the Relationship between Job Satisfaction and Organizational Commitment

\begin{tabular}{|c|c|}
\hline Range & Qualitative Interpretation \\
\hline 1.00 & Perfect Correlation $(\mathrm{P})$ \\
\hline $0.91-0.99$ & Very High Correlation (VH) \\
\hline $0.71-0.90$ & High Correlation (H) \\
\hline $0.41-0.70$ & Moderate Correlation (M) \\
\hline $0.21-0.40$ & Slight/Low Correlation (L) \\
\hline $0-0.20$ & Negligible Correlation $(\mathrm{N})$ \\
\hline
\end{tabular}

\subsection{Data Collection Procedure}

The following steps were done to pursue this research. The researcher sought permission from the Chancellor of the SPUS in conducting the research. It was followed by the giving/sending the letter of request to the different school heads which were accompanied by a letter of permission coming from the SPUS Chancellor. After which, the researcher floated the questionnaire to the participants.

Data from the questionnaires were entered into a database using the Statistical Package for the Social Sciences (SPSS). The data gathered were analyzed and interpreted using the following statistical treatments: Frequency and percentage distribution were used to confirm statistical assumptions and to describe the participants' profile in terms of the identified variables. The weighted mean was used to interpret the responses obtained from the use of the Likert's scale. The regression analysis was used to determine the best predictors of job satisfaction, and organizational commitment while Pearson and Chi-Square were used to determine the degree of relationship between the variables.

\section{Results and Discussions}

Problem Statement \#1: What is the profile of the participants?

The table shows that the participants in the four selected institutions of the SPUS are female dominated with 92 or $71.32 \%$ and only 43 or $26.36 \%$ are male. It also reveals that those whose ages are $31-35$ years has the highest percentage among the participants in the four selected schools with 34 or $26.36 \%$ followed by those whose ages belonging to $36-40$ bracket with 21 or $16.28 \%$. This is followed by those whose age brackets were belonging to $26-30$ and 41-45 years old with 17 or $13.18 \%$ on each bracket. Age brackets 46-50 and 51-55 also has the same frequency that is 14 or $10.85 \%$. Ages $56-60$ are only 7 or $5.43 \%$. The lowest percentage belongs to those whose ages are $21-25$ years old with 4 or $3.10 \%$.

As divulged in the table, the participants who are married have the most significant percentage among the participants with 93 or $72.09 \%$ and those with single status barely are 32 or $26.36 \%$. Moreover, the data shows that the participants with the highest percentage are those who have served the University system from between 6-10 years with a frequency of 34 or $26.4 \%$. There are 24 or $18.6 \%$ who have been employed for $11-15$ years, 20 or $15.5 \%$ are employed for 5 years and below, followed closely by those who have been employed for 16-20 years with a frequency of 19 or $14.7 \%, 14$ or $10.9 \%$ are on the bracket of $26-30$ years and 11 or $8.5 \%$ have been employed for $26-30$ years. The least number of participants are those who have been working in the system for 31 years and above with 4 or $3.1 \%$. The table also reveals that the highest percentages of participants are those with a master's degree with 51 or $39.53 \%$, followed by those with doctoral units with 34 or $26.36 \%$. There are 23 or $17.83 \%$ who have doctoral degrees among the participants, 16 or $12.40 \%$ have master's units, 2 or $1.55 \%$ with a bachelor's degree and 1 or . $78 \%$ with Bachelor of Laws.

Further, the table presents that the majority of the participants are faculty members without administrative assignments with a frequency of 100 or $77.22 \%$ and only 25 or $19.38 \%$ are the faculty members who at the same time are holding administrative positions. The data also reveals that the highest percentage of participants are those who are earning Php15,000 and below with 53 or $41.09 \%$, followed by those who are earning Php15,001 - Php20,000 with 44 or $34.11 \%$. Seventeen or $13.18 \%$ are earning Php20, 001 - Php25, 000 and the rest are earning Php25,001 - Php30,000 with 5 or $3.88 \%$ and finally 8 or $6.20 \%$ earn Php30,001 and above. 
Table 6. Demographic Data

\begin{tabular}{|c|c|c|}
\hline Sex & Frequency (f) & Percentage $(\%)$ \\
\hline Male & 43 & $26.36 \%$ \\
\hline Female & 92 & $71.32 \%$ \\
\hline Missing & 3 & $2.33 \%$ \\
\hline Total & 129 & $100.00 \%$ \\
\hline Age & Frequency (f) & Percentage (\%) \\
\hline $21-25$ years old & 4 & $3.10 \%$ \\
\hline $26-30$ years old & 17 & $13.18 \%$ \\
\hline $31-35$ years old & 34 & $26.36 \%$ \\
\hline $36-40$ years old & 21 & $16.28 \%$ \\
\hline $41-45$ years old & 17 & $13.18 \%$ \\
\hline $46-50$ years old & 14 & $10.85 \%$ \\
\hline $51-55$ years old & 14 & $10.85 \%$ \\
\hline $56-60$ years old & 7 & $5.43 \%$ \\
\hline Total & 128 & $99.22 \%$ \\
\hline Missing & 1 & $.78 \%$ \\
\hline Total & 129 & $100.00 \%$ \\
\hline Civil Status & Frequency (f) & Percentage (\%) \\
\hline Single & 34 & $26.36 \%$ \\
\hline Married & 93 & $72.09 \%$ \\
\hline Widowed & 2 & $1.55 \%$ \\
\hline Total & 129 & $100.00 \%$ \\
\hline Years of Service & Frequency (f) & Percentage $(\%)$ \\
\hline 5 years and below & 20 & $15.5 \%$ \\
\hline $6-10$ years & 34 & $26.4 \%$ \\
\hline $11-15$ years & 24 & $18.6 \%$ \\
\hline $16-20$ years & 19 & $14.7 \%$ \\
\hline $21-25$ years & 11 & $8.5 \%$ \\
\hline $26-30$ years & 14 & $10.9 \%$ \\
\hline 31 years and above & 4 & $3.1 \%$ \\
\hline Total & 126 & $97.7 \%$ \\
\hline Missing & 3 & $2.3 \%$ \\
\hline Total & 129 & $100.00 \%$ \\
\hline Highest Ed. attainment & Frequency (f) & Percentage $(\%)$ \\
\hline Bachelor's Degree & 2 & 1.55 \\
\hline With Master Units & 16 & 12.40 \\
\hline Master's Graduate & 51 & 39.53 \\
\hline With Doctoral Units & 34 & 26.36 \\
\hline Doctoral Graduate & 23 & 17.83 \\
\hline Bachelor of Laws & 1 & .78 \\
\hline Total & 127 & 98.45 \\
\hline Missing & 2 & 1.55 \\
\hline Total & 129 & $100.00 \%$ \\
\hline Designation & Frequency (f) & Percentage (\%) \\
\hline Faculty & 100 & $77.52 \%$ \\
\hline Administrator & 25 & $19.38 \%$ \\
\hline Total & 125 & $96.90 \%$ \\
\hline Missing & 4 & $3.10 \%$ \\
\hline Total & 129 & $100.00 \%$ \\
\hline $\begin{array}{rr}\text { Salary } \\
\end{array}$ & Frequency (f) & Percentage (\%) \\
\hline Php15 \& Below & 53 & $41.09 \%$ \\
\hline Php15,001-20,000 & 44 & $34.11 \%$ \\
\hline Php20,001-25,000 & 17 & $13.18 \%$ \\
\hline Php25,001-30,000 & 5 & $3.88 \%$ \\
\hline Php30,001 \% Above & 8 & $6.20 \%$ \\
\hline Total & 127 & $98.45 \%$ \\
\hline Missing & 2 & $1.55 \%$ \\
\hline Total & 129 & $100.00 \%$ \\
\hline
\end{tabular}


Problem Statement \#2: What describes the organizational culture of the faculty of SPUS?

Table 7. Mean and Descriptive Interpretation of the Dominant Culture Type of Each of the Participating Institutions in the Actual Situation (now)

\begin{tabular}{lccccc}
\hline \multicolumn{1}{c}{ Institution } & Clan & Hierarchy & Adhocracy & Market & Description \\
\hline School A & 25.35 & 23.81 & 28.29 & 22.62 & Adhocracy \\
School B & 42.18 & 20.43 & 19.62 & 19.39 & Clan \\
School C & 43.22 & 24.17 & 15.56 & 17.67 & Clan \\
School D & 40.39 & 21.74 & 18.82 & 18.94 & Clan \\
\hline
\end{tabular}

The table shows the mean scores obtained in the four culture types for the current situation. It further reveals that the dominant type of culture exhibited by the faculty of Schools B, C, and D is a Clan-oriented which means that the organization concentrates most on internal with flexibility, concern for people, and sensitivity for customers. These institutions are described as family oriented, and they focused on mentoring, nurturing, and "doing things together." School A has a unique dominant culture type which is Adhocracy which means that in this institution, the organization concentrates most on external positioning with a high degree of flexibility and individuality, dynamic and entrepreneurial. Moreover, this institution is focused on risk-taking, innovation, and "doing things first."

Table 8. Mean and Descriptive Interpretation of the Dominant Culture Type of Each of the Participating Institutions in the Preferred Situation

\begin{tabular}{lccccc}
\hline \multicolumn{1}{c}{ Institution } & Clan & Hierarchy & Adhocracy & Market & Description \\
\hline School A & 35.65 & 22.29 & 20.10 & 19.61 & Clan \\
School B & 43.47 & 21.86 & 20.79 & 19.73 & Clan \\
School C & 45.83 & 22.94 & 12.67 & 19.06 & Clan \\
School D & 40.92 & 21.67 & 18.54 & 18.83 & Clan \\
\hline
\end{tabular}

The table shows the mean scores obtained from the preferred culture types of participants. Interestingly, there is commonality on the preferred culture type of participants. The schools prefer a clan-oriented culture. The result implies that the faculty in the selected schools has a shared common vision that is to create a family-oriented culture which focuses on mentoring, nurturing, concern for people and sensitivity to others. The result further conveys the unique culture of every Paulinian school as they are formed to be "Paulinian for others," and being an "All to all," which means having concern for others, to love and serve one another and concern for the least, the lost and the last. By virtue of the Catholicity of the Paulinian schools, this vision draws its nature from Jesus Christ as seen in his genuine love and concern for others. The dominant clan-oriented culture type which the participants prefer most reflects the genuine identity of every Paulinian.

Problem Statement \#3: What describes the level of organizational commitment of the faculty of SPUS?

Table 9. Mean and Qualitative Interpretation (QI) of the Level of Organizational Commitment (OC) of the Members of the Faculty of the Participating Schools

\begin{tabular}{|c|c|c|c|c|c|c|c|c|}
\hline \multirow[t]{2}{*}{ OC Domains } & \multicolumn{2}{|c|}{ School A } & \multicolumn{2}{|c|}{ School B } & \multicolumn{2}{|c|}{ School C } & \multicolumn{2}{|c|}{ School D } \\
\hline & $\mathrm{X}$ & QI & $\mathrm{X}$ & QI & $\mathrm{X}$ & QI & $\mathrm{X}$ & $\mathrm{QI}$ \\
\hline Affective & 5.05 & $\mathrm{AL}$ & 5.50 & $\mathrm{AL}$ & 5.43 & $\mathrm{AL}$ & 5.70 & $\mathrm{HL}$ \\
\hline Continuance & 4.20 & $\mathrm{AL}$ & 4.64 & $\mathrm{AL}$ & 4.73 & $\mathrm{AL}$ & 5.07 & $\mathrm{AL}$ \\
\hline Normative & 4.93 & $\mathrm{AL}$ & 5.68 & HL & 5.39 & $\mathrm{AL}$ & 5.80 & $\mathrm{HL}$ \\
\hline
\end{tabular}

The table discloses that School A's affective commitment is at an average level (AL) with a mean score of 5.05. Continuance commitment is likewise at an average level with an equivalent mean score of 4.20 which is also the same level with normative commitment with a mean score of 4.93. Generally, the faculty with permanent status in School A has an average level of commitment. The data implies that the faculty members of School A can identify themselves with the goals of the organization at an average level. It further implies that they have the desire to remain as members of the organization. The attachment of the faculty members can be attributed to the relationship they maintain with their fellow employees, which means that they can relate well despite their differences. Their desire to remain with the organization is also because they can find themselves as being part of the productivity and 
success of the organization. Moreover, their affective commitment is also a manifestation of their belief and appreciation of the Paulinian core values. Their job, too, has a favorable and very favorable influence which makes them emotionally attached to their institution. The continuance commitment of the participants of School A reveals that their benefits as favorable and very favorable and further reveal that the participants feel that it is practical to remain in their institution since they are satisfied with their benefits. Their normative commitment reveals a feeling of being obliged to remain in their institution because of some moral or ethical reasons, i.e., it is their primary role to mold the young minds of their students. They believe that it is not right to leave their institution now.

The table further reveals that the affective and continuance commitment of School B is both at an average level with mean scores of 5.50 and 4.64 respectively. The normative commitment has a mean score of 5.68 which signifies a high level of organizational commitment. The continuance commitment of the participants is also due in part of a favorable compensation.

It is interesting to note that there is a high level of normative commitment among the participants of School B. They believe that it would not be right for them to leave their institution because they sense that they also have a moral obligation to their students, fellow employees and the administration. Moreover, the table reveals the commitment of the participants in School C. It shows that the participants' affective commitment is at an average level with a mean score of 5.43. The continuance commitment is also described as average, and it is similar to their normative commitment with mean scores of 4.43 and 5.39 respectively.

Lastly, the table reveals that the participants' commitment in School D signifies a high level of affective and normative commitment with mean scores of 5.70 and 5.80 respectively. Their continuance commitment is at an average level with a mean score of 5.07. The result implies that the participants have a strong attachment to their institution and that they sense that they need to maintain their membership to the institution.

Problem Statement \#4: What describes the job satisfaction of the faculty of SPUS?

Table 10. Mean and Qualitative Interpretation (QI) of the Level of Job Satisfaction of the Participants in the Respondent-Institutions

\begin{tabular}{lllllllll}
\hline & \multicolumn{2}{l}{ School A } & \multicolumn{2}{l}{ School B } & \multicolumn{2}{l}{ School C } & \multicolumn{2}{l}{ School D } \\
\cline { 2 - 9 } Facets of Job Satisfaction & X & QI & X & QI & X & QI & X & QI \\
\hline Relationship with Immediate Head & 3.17 & S & 3.24 & S & 3.25 & VS & 3.58 & VS \\
Interdepartmental Relationship & 2.75 & S & 3.04 & S & 2.84 & S & 3.54 & VS \\
Physical Environment & 2.95 & S & 3.39 & VS & 3.19 & S & 3.65 & VS \\
Relationship with co-employees & 3.08 & S & 3.20 & S & 3.28 & VS & 3.63 & VS \\
Compensation & 2.52 & S & 3.01 & S & 2.85 & S & 3.51 & VS \\
Job Identification & 3.24 & S & 3.37 & VS & 3.37 & VS & 3.72 & VS \\
Overall attitude toward work & 3.17 & S & 3.48 & VS & 3.36 & VS & 3.68 & VS \\
Clarity of Work Group & 3.11 & S & 3.22 & S & 3.19 & S & 3.62 & VS \\
Implementations of Policies & 2.73 & S & 3.14 & S & 3.05 & S & 3.47 & VS \\
Management & 2.62 & S & 2.97 & S & 2.96 & S & 3.51 & VS \\
Communication & 2.30 & D & 2.78 & S & 2.72 & S & 3.23 & S \\
Feedbacking & 2.95 & S & 2.99 & S & 3.05 & S & 3.51 & VS \\
Task Significant & 3.24 & S & 3.36 & VS & 3.25 & VS & 3.74 & VS \\
Overall Mean/Institution & 2.91 & S & 3.17 & S & 3.10 & S & 3.57 & VS \\
\hline Overall Satisfaction Level of the Respondent-Institutions & & & & 3.19 Satisfied \\
\hline
\end{tabular}

The results indicate that the participants of School A generally are satisfied in terms of all the facets of job satisfaction. The area of communication is quite disturbing because it indicates dissatisfaction among the participants of School A. In any organization, communication is vital in its operation. There are underlying theories about communication why it is essential in the organization. Communication fosters motivation by classifying what it is to be done. The formation of specific goals, feedback on progress towards the goal, and reinforcement of desired behavior all stimulate motivation which requires communication. The communication which takes place within the organization is a fundamental mechanism by which the members show their emotional expression which maybe their feelings of frustrations or satisfaction (Robin \& Judge, 2007). Moreover, communication provides information to make decisions by transmitting the data to identify and evaluate choices. Though generally, the participants show satisfaction in most of the job facets, its implications to management is to become aware that they need to raise the 
satisfaction level of the faculty members by focusing on the intrinsic parts of the job.

For School B, the table shows that in all facets of job satisfaction the participants show satisfaction to a varying degree. The areas on the physical environment, job identification, overall attitude towards work and task significance, show that the participants are very satisfied. Generally, the participants of School B are delighted with the condition of their job.

Further, the participants of School C show satisfaction in all the facets of job satisfaction. The participants show a high level of satisfaction in areas such as the relationship with their immediate head, relationship with their fellow employees, job identification, overall attitude towards work and task significance. This implies that Schools B and C generally are satisfied with their working condition in their respective institution.

Finally, the participants of School D show a very high level of satisfaction in all facets excluding communication which was rated only as "satisfied." The result of their assessment is indicative of their job condition which means that the participants of School D are happy and productive workers. Generally, all participants are satisfied with their job as shown in the mean score of 3.57. The overall satisfaction level of the participants is 3.19 which implies that they are satisfied with their present job.

Problem Statement \#5: Is there a significant relationship between organizational culture and job satisfaction?

Table 11. The Significant Relationship of Organizational Culture and Job Satisfaction of the Respondent-Institutions Using The Pearson Chi-Square Analysis

\begin{tabular}{lccc}
\hline \multicolumn{1}{c}{ Job Satisfaction } & Person $\mathrm{r}$ & Probability & Remarks \\
\hline Clan & $0.277^{*}$ & .002 & Significant \\
Hierarchy & $-0.190^{*}$ & .034 & Significant \\
Adhocracy & $-0.272^{* *}$ & .002 & Significant \\
Market & -0.046 & .611 & Not Significant \\
\hline ** Correlation is significant at the 0.01 level (2-tailed) * Correlation is significant at the 0.05 level (2-tailed).
\end{tabular}

Pearson chi-square analysis of 0.05 and 0.01 level of significance was used to determine the correlation between job satisfaction and organizational culture. The table shows a significant positive relationship between job satisfaction and clan. This finding consistently shows that the participants in the respondent-institutions prioritize a unique need for having a clan-oriented culture. It further reveals a negative relationship between job satisfaction with the three culture profiles such as hierarchy, adhocracy, and market-oriented culture. The market-oriented culture shows no significant relationship in the job satisfaction level of the participants of the respondent-institutions. These findings find support in a study conducted by Lund (2003) that job satisfaction was positively related to clan and adhocracy cultures, and negatively related to market and hierarchy cultures.

Mckinnon et al. (2003) believes that there is quite a compelling support for the importance of organizational culture in affecting job satisfaction. Harris \& Mossholder (1996) also pointed out that organizational culture stands as the center from which all other factors of human resource management are derived. They confirmed that organizational culture influences individuals' attitudes concerning outcomes, such as commitment, motivation, morale, and satisfaction.

Problem Statement \#6: Is there a significant relationship between job satisfaction and organizational commitment?

Pearson and chi-Square analysis at 0.05 and 0.01 level were conducted to determine the correlation between job satisfaction and organizational commitment and interestingly, only one component of job satisfaction (task significant) did not predict organizational commitment (continuance commitment). All the rest of the job satisfaction components predict organizational commitment such as affective, continuance and normative commitment. This suggests that generally, the 12 components of job satisfaction which are the relationship with immediate head, interdepartmental relationship, relationship with co-employees, compensation, job identification, overall attitude toward work, clarity of workgroup, implementations of policies, management, communication and feedbacking affect the commitment of the participants. Moreover, the result varies from low correlation to moderate correlation. 
Table 12. Significant Relationship of Job Satisfaction and Organizational Commitment of the Respondent-Institutions Using the Pearson and Chi-Square Analysis

\begin{tabular}{lcccccc}
\hline \multicolumn{1}{c}{ Facets of Job Satisfaction } & $\begin{array}{c}\text { Affective } \\
\text { Commitment }\end{array}$ & QI & $\begin{array}{c}\text { Continuance } \\
\text { Commitment }\end{array}$ & QI & $\begin{array}{c}\text { Normative } \\
\text { Commitment }\end{array}$ & QI \\
\hline Relationship with Immediate Head & $.209^{*}$ & $\mathrm{~L}$ & $.214^{*}$ & $\mathrm{~L}$ & $.272^{* *}$ & $\mathrm{~L}$ \\
Interdepartmental Relationship & $.393^{* *}$ & $\mathrm{~L}$ & $.270^{* *}$ & $\mathrm{~L}$ & $.457^{* *}$ & $\mathrm{M}$ \\
Physical Environment & $.499^{* *}$ & $\mathrm{M}$ & $.255^{* *}$ & $\mathrm{~L}$ & $.522^{* *}$ & $\mathrm{M}$ \\
Relationship with Co-employees & $.362^{* *}$ & $\mathrm{~L}$ & $.192^{*}$ & $\mathbf{N}$ & $.424^{* *}$ & $\mathrm{M}$ \\
Compensation & $.458^{* *}$ & $\mathrm{M}$ & $.344^{* *}$ & $\mathrm{~L}$ & $.613^{* *}$ & $\mathrm{M}$ \\
Job Identification & $.331^{* *}$ & $\mathrm{~L}$ & $.185^{*}$ & $\mathbf{N}$ & $.468^{* *}$ & $\mathrm{M}$ \\
Overall Attitude Towards Work & $.350^{* *}$ & $\mathrm{~L}$ & $.251^{* *}$ & $\mathrm{~L}$ & $.523^{* *}$ & $\mathrm{M}$ \\
Clarity of Work Group & $.304^{* *}$ & $\mathrm{~L}$ & $.317^{* *}$ & $\mathrm{~L}$ & $.326^{* *}$ & $\mathrm{~L}$ \\
Implementation of Policies & $.458^{* *}$ & $\mathrm{M}$ & $.334^{* *}$ & $\mathrm{~L}$ & $.596^{* *}$ & $\mathrm{M}$ \\
Management & $.450^{* *}$ & $\mathrm{M}$ & $.353^{* *}$ & $\mathrm{~L}$ & $.631^{* *}$ & $\mathrm{M}$ \\
Communication & $.434^{* *}$ & $\mathrm{M}$ & $.354^{* *}$ & $\mathrm{~L}$ & $.563^{* *}$ & $\mathrm{M}$ \\
Feedbacking & $.258^{* *}$ & $\mathrm{~L}$ & $.290^{* *}$ & $\mathrm{~L}$ & $.327^{* *}$ & $\mathrm{~L}$ \\
Task Significance & $.420^{* *}$ & $\mathrm{M}$ & .134 & $\mathrm{~L}$ & $407^{* *}$ & $\mathrm{~L}$ \\
\hline
\end{tabular}

** Correlation is significant at the 0.01 level (2-tailed). * Correlation is significant at the 0.05 level (2-tailed).

\section{Conclusions}

Based on the findings of this present study, the researcher concludes that culture develops over some time and, in the process of developing, acquires significantly deeper meaning. Creating an organizational culture that values and respects each member of the organization is effective in producing higher levels of organizational commitment. Satisfied employees increase organizational loyalty and more likely to talk positively about their organization, help others, and go beyond the reasonable expectations in their job. On the contrary, the faculty who are not satisfied cannot foster a pleasant learning environment and may prove to be disruptive to campus harmony. Furthermore, such discord would not facilitate the retention and success of students, since a large percentage of students' formal interaction is with the faculty.

Organizational culture provides the "glue" which holds the employees together, stimulates their commitment to common mission, and galvanizes their creativity and energy. It plays a significant role in shaping the responsiveness, quality, problem-solving ability and distinctive competence of every organization. It can be a driver of employees' attitude and organizational effectiveness and performance. Thus, creating an organizational culture that values and respects each member of the organization is effective in producing a higher level of organizational commitment and job satisfaction. The higher level of organizational commitment is associated with more favorable organizational culture and greater job satisfaction.

There are limitations to this present study, and the author cannot assume that the results can be applied to all organizations. The samples used are faculty members in selected private schools in the Philippines. Future researchers may focus on the limitations and work at improving the generality of the results.

\section{References}

Anastacio, S. E. L. (2016). Balanced scorecard model for Paulinian educational institutions. International Journal of Curriculum and Instruction, 8(1), 69-89.

Berrio, A. A. (2003). An organizational culture assessment using the competing values framework: A profile of Ohio State University Extension. Age, 2(699), 1-052.

Blance, C., \& Menes, C. (n.d.). Organizational commitment and job satisfaction of employees in a retail establishment. Retrieved from http://lcc.edu.ph/assets/images/research/pdf/Organizational\%20Commitment.pdf?id=uploads/archive/LCCB/Vo $1 . \% 2$ 02\%20No.\%201\%20(2013)/Articles/01_Wa-Mbaleka.pdf\&di=6625

Brown, W. A., \& Yoshioka, C. F. (2003). Mission attachment and satisfaction as factors in employee retention. Nonprofit management and leadership, 14(1), 5-18. https://doi.org/10.1002/nml.18

Cameron, K. S., \& Quinn, R. E. (2000). Diagnosing and changing organizational culture, based on the competing values framework, 1999. Reading, Massachusettes: Addison Wesley. 
Cooke, R. A., \& Szumal, J. L. (1993). Measuring normative beliefs and shared behavioral expectations in organizations: The reliability and validity of the Organizational Culture Inventory. Psychological reports, 72(3_suppl), 1299-1330. https://doi.org/10.2466/pr0.1993.72.3c.1299

Dadgar, H., Barahouei, F., Mohammadi, M., Ebrahimi, M., \& Ganjali, A. (2013). The relationship between organizational culture, job satisfaction, organizational commitment and intention to stay of health personnel's of Zahedan University of Medical Sciences. World Applied Sciences Journal, 21(8), 1220-1228. https://doi.org/10.5829/idosi.wasj.2013.21.8.108

Harris, S. G., \& Mossholder, K. W. (1996). The affective implications of perceived congruence with culture dimensions during organizational transformation. Journal of management, 22(4), 527-547. https://doi.org/10.1177/014920639602200401

Hosseinkhanzadeh, A. A., Hosseinkhanzadeh, A., \& Yeganeh, T. (2013). Investigate relationship between job satisfaction and organizational culture among teachers. Procedia-Social and Behavioral Sciences, 84, 832-836. https://doi.org/10.1016/j.sbspro.2013.06.656

Jill, A. W. C. W. C., McKinnon, L., \& Harrison, G. L. (2003). Organizational cultural: association with commitment, job satisfaction, propensity to remain, and information sharing in Taiwan. Journal of Development Studies, 39(6), $1-22$.

Kwon, Y. (2002). A process model of organizational commitment of Korean government employees: The effects of organizational practices, role ambiguity, and trust on altruism. International Review of Public Administration, 7(2), 81-97.https://doi.org/10.1080/12294659.2002.10805008

Larson, M., \& Luthans, F. (2006). Potential added value of psychological capital in predicting work attitudes. Journal of leadership \& organizational studies, 13(2), 75-92. https://doi.org/10.1177/10717919070130020601

Lim, T. (2010). Relationships among organizational commitment, job satisfaction, and learning organization culture in one Korean private organization. Asia Pacific Education Review, 11(3), 311-320. https://doi.org/311-320. $10.1007 / \mathrm{s} 12564-010-9087-\mathrm{z}$

Lok, P., \& Crawford, J. (1999). The relationship between commitment and organizational culture, subculture, leadership style and job satisfaction in organizational change and development. Leadership \& Organization Development Journal, 20(7), 365-374. https://doi.org/10.1108/01437739910302524

Lund, D. B. (2003). Organizational culture and job satisfaction. Journal of business \& industrial marketing, 18(3), 219-236. https://doi.org/10.1108/0885862031047313

Mak, J. T. K. (1998). An ethnographic study of school culture, teachers' job satisfaction and organizational commitment in a selected New Zealand secondary school: a thesis submitted to the Faculty of Education, Massey University for the degree of Doctor of Philosophy (Doctoral dissertation, Massey University). http://hdl.handle.net/10179/4044

Markovits, Y., Davis, A. J., \& Van Dick, R. (2007). Organizational commitment profiles and job satisfaction among Greek private and public sector employees. International Journal of Cross Cultural Management, 7(1), 77-99. https://doi.org/10.1177/1470595807075180

McShane, S. T., \& Von Glinow, M. (2008). Organizational behavior (4th ed.). New York: McGraw-Hill/Irwin Companies, Inc.

Nacpil, L. E., \& Lacap, J. P. G. (n.d.) Job satisfaction and organizational commitment: The case of employees of a government agency in Region III, Philippines. Retrieved from https://www.researchgate.net/profile/Jean_Paolo_Lacap/publication/325438433_Job_Satisfaction_and_Organiz ational_Commitment_The_Case_of_Employees_of_a_Government_Agency_in_Region_III_Philippines/links/5 b0df2834585157f872231b0/Job-Satisfaction-and-Organizational-Commitment-The-Case-of-Employees-of-a-G overnment-Agency-in-Region-III-Philippines.pdf

Noordin, F., Omar, S., Sehan, S., \& Idrus, S. (2010). Organizational climate and its influence on organizational commitment. International Business \& Economics Research Journal, 9(2), 1-10. https://doi.org/10.19030/iber.v9i2.516

Porter, L. W., Steers, R. M., Mowday, R. T., \& Boulian, P. V. (1974). Organizational commitment, job satisfaction, and turnover among psychiatric technicians. Journal of applied psychology, 59(5), 603. http://dx.doi.org/10.1037/h0037335 
Quiambao D T., \& Nuqui A. (2017). Determinants of organizational commitment among the faculty members of private tertiary institutions. Journal of Social Sciences \& Humanities Research, 3(1), 2017 Feb 3 [last modified: 2017 Feb 6]. Edition 1.

Robbins, S. P., \& Judge, T. A. (2007). An Introduction to organizational behavior (12th ed.). Jurong Singapore: Prentice Hall, Pearson, Education Inc.

Saturay, J. G. R. S. L. (nd). Individual differences in adaptation to work dissatisfaction. Retrieved from http://leeds-faculty.colorado.edu/rosse/Research/WAM04\%20presentation.pdf

Sikorska-Simmons, E. (2005). Predictors of organizational commitment among staff in assisted living. The Gerontologist, 45(2), 196-205. https://doi.org/10.1093/geront/45.2.196

Silverthorne, C. (2004). The impact of organizational culture and person-organization fit on organizational commitment and job satisfaction in Taiwan. Leadership \& Organization Development Journal, 25(7), 592-599. https://doi.org/10.1108/01437730410561477

Sockel, H. Y., \& Mak, B. (2004). The relationship of perceived organizational innovativeness (PORGI) on IS\&T employee continuance: A Lisrel model. International Journal of Innovation and Technology Management, 1(04), 393-414. https://doi.org/10.1142/S0219877004000295

Uii, Muafi. (2011). Causes and consequence deviant workplace behavior. 2. Retrieved from https://www.researchgate.net/publication/323392841_Causes_and_consequence_deviant_workplace_behavior

Utami, W., Farida, L., Azalia, N., \& Lutfi, M. (2017). The influence of organizational culture and job satisfaction on organizational citizenship behavior (OCB) with organizational commitment as intervening variable at PT. Cartenz Indonesia in Solo City-Indonesia. Advanced Science Letters, 23(12), 11848-11852. https://doi.org/10.1166/asl.2017.10530

Welsch, H. P., \& LaVan, H. (1981). Inter-relationships between organizational commitment and job characteristics, job satisfaction, professional behavior, and organizational climate. Human relations, 34(12), 1079-1089. https://doi.org/10.1177/001872678103401205

Williams, L. J., \& Anderson, S. E. (1991). Job satisfaction and organizational commitment as predictors of organizational citizenship and in-role behaviors. Journal of management, 17(3), 601-617. https://doi.org/10.1177/014920639101700305

Yousef, D. A. (2001). Islamic work ethic-A moderator between organizational commitment and job satisfaction in a cross-cultural context. Personnel review, 30(2), 152-169. https://doi.org/10.1108/00483480110380325 